\title{
Use of Oral Misoprostol, Intramuscular Oxyłocin and Intravenous Methergin in Prevention of Postpartum Haemorrhage
}

\author{
Meena $\mathbf{B L}^{1}$ \\ ${ }^{1}$ Department of Obstetrics and Gynaecology, SP Medical College, Bikaner, Rajasthan, India.
}

\begin{abstract}
Aims: The purpose of the study was to compare the efficacy of misoporstol 600mg orally (Group A), injection oxytocin 10 IU intramuscularly (Group B) and injection methylergometrine $0.2 \mathrm{mg}$ intravenously (Group C) on reducing blood loss in third stage of labour, duration of third stage of labour, effect on haemoglobin of the patient, need of additional oxytocics or blood transfusion and associated side effects and complications.
\end{abstract}

Methods: A prospective study enrolling 510 women and randomising them into three groups was done in S P Medical College, Bikaner, Rajasthan, India. Active management of third stage of labour was done using one of the three uterotonics as per the group of the patient.

Results: Methylergometrine was superior to rest of the drugs with lowest duration of third stage of labour $(p=0.02)$, lowest amount of blood loss $(p=0.0001)$ and lowest rate of post partum hemorrhage $(p=0.08)$. The need of additional oxytocics and blood transfusion was highest with oral misoprostol as compared to all other drugs used in the study with $\mathrm{p}$ value of 0.08 and 0.009 respectively.

Conclusions: Methylergometrine has the best uterotonic drug profile amongst the drugs used, strongly favouring its routine use as oxytocic for active management of third stage of labour. Oral misoprostol resulted in a higher blood loss compared to other drugs and hence it should be used only in low-resource settings where other drugs are not available. However, a large multi-centre study is needed for the confirmation of the finding.

Keywords: post partum hemorrhage, third stage of labour, uterotonic.

INTRODUCTION

Postpartum hemorrhage (PPH) is the most serious complication in obstetrics. The greatest number of maternal deaths from hemorrhage is due to PPH, which is almost entirely a preventable condition. It occurs in approximately $4 \%$ of vaginal deliveries, and estimates are that it causes significant morbidity and $25 \%$ of all the maternal child birth related death. ${ }^{1}$ WHO defines $\mathrm{PPH}$ as blood loss of $500 \mathrm{ml}$ or more in first 24 hours post partum. ${ }^{2}$ Post partum blood loss is difficult to evaluate especially in developing countries where most of the women are anaemic with poor reserve and this condition is further aggravated by increased demand during pregnancy and blood loss during third stage of labour. ${ }^{3}$ The days of expectant management, the so called "hands off" ${ }^{4}$ approach seems to be over, in view of serious consequences of PPH. An attempt was hence made to study the efficacy of various oxytocics like oxytocin, methylergometrine and misoprostol in reducing blood loss in active management of third stage labour.

\section{CORRESPONDENCE}

Dr Banwari Lal Meena

Department of Obstetrics and Gynaecology,

S.P. Medical College, Bikaner, Rajasthan, India.

Email : banwarilalmeen1983@gmail.com

Phone : +919549607044

\section{METHODS}

A randomized study was carried out in SP Medical College, Bikaner from Jan 2011 to Jan 2012. A total of 510 women were enrolled in the study. Women were allotted to one of the three groups once they fulfilled all the selection criteria. Active management of third stage of labor was done in Group A with misoprostol 600 mg orally, Group B with injection oxytocin 10 IU intramuscularly and Group $\mathrm{C}$ with injection methylergometrine $0.2 \mathrm{mg}$ intravenously after the delivery of the baby.

Women with singleton pregnancy, between 37 and 42 weeks of gestation, anticipated vaginal delivery, vertical lie, no high risk factors and who gave written and informed consent were enrolled in the study. While women with hemoglibin $<8$ gm\%, pregnancy induced hypertension, abruption placentae, marginal placenta previa/low lying placenta, multiple pregnancy, grandmultipara, malpresentation, polyhydramnios, previous uterine scar, chorioamnionitis, prolonged labor, intrauterine fetal death, coagulation abnormalities were excluded. Patients

The papers in this journal are published under the terms of the Creative Commons Attribution License. Users are allowed to read, download, copy, distribute, print, search, or link to the full texts of the articles in this journal without asking prior permission from the publisher or the author. 
with history of medical disorders like asthma, epilepsy, heart or renal disease were also excluded from the study. After this calibrated BRASS V(R) DRAPE (5) was kept under the buttocks of the patient in such a way that whatever blood used to come out was collected in the receptacle.

We avoided traction on the umbilical cord, until there was evidence of placental separation. As soon as signs of placental separation appeared the placenta was delivered by controlled cord traction. Time interval between the delivery of the baby and the placenta was noted. Pulse rate, temperature and blood pressure were recorded one hour after delivery. Patient was kept in labor room under observation for a period of two hours. Any complaint such as nausea, vomiting, fever, headache, chills, diarrhoea and shivering was noted. In case of marked bleeding and uterus remaining flabby, uterus was massaged and PGF2a 250 mcg was given intramuscularly. Inspection of vulva for perineal tears and per speculum examination for cervical tear was carried out. A repeat hemoglobin estimation was done and third post partum day after 48 hour. Statistical analysis was performed using student's $t$ test for continuous variables and the $x^{2}$ and fisher's exact test for categorical data. $P$ value of $<0.05$ was considered statistically significant.

\section{RESULTS}

The women in all the three groups were comparable in regards to their age, weeks of gestation and mode of onset of labor (Table 1).

Table 1. Demographic variables of the women $(n=510)$.

\begin{tabular}{|c|c|c|c|c|c|}
\hline Parameters & $\begin{array}{l}\text { Misoprostol } \\
\text { ( } n=170\end{array}$ & $\begin{array}{l}\text { Oxytocin } \\
(n=170)\end{array}$ & $\begin{array}{l}\text { Methyl- } \\
\text { ergometrine } \\
(\mathrm{n}=170)\end{array}$ & $P$ value & $\begin{array}{l}x^{2} \\
\text { value }\end{array}$ \\
\hline $\begin{array}{l}\text { Mean age } \\
\text { (years) }\end{array}$ & 23.25 & 23.39 & 23.65 & 0.18 & 1.60 \\
\hline $\begin{array}{l}\text { Gestational } \\
\text { age at } \\
\text { delivery }\end{array}$ & $\begin{array}{ll}38.2 & \pm \\
1.022 & \end{array}$ & $\begin{array}{l}38.2 \quad \pm \\
0.99\end{array}$ & $39.1 \pm 0.98$ & 0.113 & 2.07 \\
\hline $\begin{array}{l}\text { Mode of } \\
\text { labour }\end{array}$ & & & & & \\
\hline $\begin{array}{l}\text { Induced } \\
\text { labor }\end{array}$ & $51(30 \%)$ & $68(40 \%)$ & $51(30 \%)$ & 0.93 & 0.42 \\
\hline $\begin{array}{l}\text { Spontaneous } \\
\text { labor }\end{array}$ & $119(70 \%)$ & $\begin{array}{l}102 \\
(60 \%)\end{array}$ & $\begin{array}{l}119 \\
(70 \%)\end{array}$ & & \\
\hline
\end{tabular}

There was no statistically significant difference among the groups as regards the duration of first and second stage of labor with $p$ value of 0.11 and 0.43 , respectively for stage one and stage two of the labor, showing that the groups were comparable. The duration of third stage of labor was significantly reduced with methylergometrine $(p=$ 0.02 ) and was lowest amongst the drugs used in the study. Methylergometrine given intravenously had immediate action and hence there was a maximum reduction in duration of third stage of labor. Misoprostol given orally had delayed onset of action and hence resulted in a longer duration of third stage of labor compared to methylergometrine. There was no significant difference between the two groups in the mean blood loss, incidence of PPH and fall in hemoglobin concentration. The need of additional oxytocic was higher in misoprostol $(R R=1.62)$ group but manual removal of placenta was reduced (RR $=0.29)$. Shivering and pyrexia were more common in the misoprostol group. The average amount of the blood loss with the three drugs in this study was 310, 286 and $258 \mathrm{ml}$, respectively with misoprostol, oxytocin and methylergometrine $(p=0.0001)$, showing that of the drugs used methylergometrine was the most effective drug in reducing the blood loss. The reduction in blood loss is particularly important in our country where most of child bearing population is anaemic. Considering PPH as a blood loss of $>500 \mathrm{ml}, 4.11 \%$ patients given misoprostol developed $\mathrm{PPH}$ as compared with 3.52 and $2.94 \%$, respectively with group $B$ and $C(p=0.08)$, which is not statistically significant. Thus among the three methylergometrine had lowest blood loss, strongly favouring its routine use as uterotonic for active management of third stage of labor. There was no significant difference in the pre-delivery and the post-delivery hemoglobin concentration amongst the three groups ( Table 2).

Table 2. Events in labor $(n=510)$.

\begin{tabular}{|c|c|c|c|c|}
\hline Parameters & $\begin{array}{l}\text { Misoprostol } \\
\text { (n=170 }\end{array}$ & $\begin{array}{l}\text { Oxytocin } \\
(n=170)\end{array}$ & $\begin{array}{l}\text { Methyl- } \\
\text { ergometrine } \\
(n=170)\end{array}$ & $\begin{array}{l}P \\
\text { value }\end{array}$ \\
\hline $\begin{array}{l}\text { Stage } 1 \text { (hr) } \\
\pm \text { SD }\end{array}$ & $9.27 \pm 1.68$ & $8.98 \pm 1.90$ & $8.79 \pm 1.61$ & 0.11 \\
\hline $\begin{array}{l}\text { Stage } 2 \text { (min) } \\
\pm \text { SD }\end{array}$ & $28.41 \pm 8.2$ & $\begin{array}{l}28.32 \\
\pm 7.76\end{array}$ & $27.56 \pm 5.14$ & 0.43 \\
\hline $\begin{array}{l}\text { Stage } 3(\min ) \\
\pm S D\end{array}$ & $4.15 \pm 0.81$ & $3.42 \pm 1.13$ & $3.28 \pm 0.78$ & 0.02 \\
\hline $\begin{array}{l}\text { Amount of } \\
\text { blood loss } \\
(\mathrm{ml}) \pm \mathrm{SD}\end{array}$ & $\begin{array}{l}310.48 \quad \pm \\
84.25\end{array}$ & $\begin{array}{l}286.11 \quad \pm \\
84.99\end{array}$ & $\begin{array}{l}258.03 \quad \pm \\
87.7\end{array}$ & .0001 \\
\hline $\begin{array}{l}\text { Blood loss of } \\
\geq 500 \mathrm{ml}\end{array}$ & $7(4.11)$ & $6(3.52 \%)$ & 5 (2.94\%) & 0.08 \\
\hline $\begin{array}{l}\text { Pre-delivery } \\
\mathrm{Hb}\end{array}$ & 9.35 & 9.25 & 9.42 & \\
\hline $\begin{array}{l}\text { Post-delivery } \\
\mathrm{Hb}\end{array}$ & 8.81 & 8.49 & 8.74 & \\
\hline $\begin{array}{l}\text { Average } \\
\text { difference } \\
(1,2) \pm S D\end{array}$ & $0.62 \pm 0.18$ & $0.66 \pm 0.17$ & $0.66 \pm 0.17$ & 0.06 \\
\hline $\begin{array}{l}\text { Percentage } \\
\text { difference }\end{array}$ & & & & \\
\hline $\begin{array}{l}\mathrm{Hb}(1.2) / \mathrm{Hb} x \\
100 \pm \mathrm{SD}\end{array}$ & $8.81 \pm 1.45$ & $7.17 \pm 1.84$ & $6.74 \pm 2.07$ & 0.14 \\
\hline $\begin{array}{l}\text { Need of } \\
\text { additional } \\
\text { Oxytocic }\end{array}$ & $7(4.11)$ & $6(3.52)$ & $5(2.94)$ & 0.08 \\
\hline $\begin{array}{l}\text { Need of } \\
\text { blood } \\
\text { transfusion }\end{array}$ & $6(3.52 \%)$ & $5(2.94)$ & $4(2.35 \%)$ & 0.06 \\
\hline
\end{tabular}


There was increased frequency of headache in patients given methylergometrine. Methylergometrine was associated with rise in blood pressure though the incidence was low and was statistically significant $(p=0.0001)$. There was higher incidence of nausea and vomiting in patients given methylergometrine as compared to other drugs. Oral misoprostol caused significantly higher rates of pyrexia and shivering ( $p=0.0001)$ as compared to other drugs. Diarrhoea was also caused more frequently with oral misoprostol.

\section{DISCUSSION}

PPH is the most serious complication in obstetrics practice. The greatest number of maternal deaths from hemorrhage is due to PPH, which is almost entirely a preventable condition. PPH occurs in approximately $4 \%$ of vaginal deliveries, and estimates are that it causes significant morbidity and $25 \%$ of all the maternal child birth related death. ${ }^{1}$

In our study mean blood loss in third stage of labour was $310 \mathrm{ml}$ in misoprostol group, $286 \mathrm{ml}$ in oxytocin group and $258 \mathrm{ml}$ in methylergometrine group. The mean blood loss in third stage of labour was lowest in methylergometrine group and difference was highly statistically significant $(p=0.0001)$. Similar results were reported in a study by Gohil et al. ${ }^{6}$

The need of additional oxytocics and blood transfusion was highest with oral misoprostol as compared to all other drugs used. The late absorption of misoprostol delays its effect in controlling hemorrhage during first hour of delivery leading to more need of oxytocic as compared to intravenous methylergometrine, which has immediate onset of action requiring rarely any additional oxytocic. Methylergometrine is associated with equal or lower blood loss as com $\neg$ pared to oxytocin and ergometrine-oxytocin in most of the studies and hence should be a preferred drug for prevention of PPH if not contraindicated (Table 2).

The mean duration of third stage of labour was 4.15 minutes in misoprostol group , 3.42 minutes in oxytocin group and 3.28 minutes in mehylergometrine group. The mean duration of third stage of labour was lowest in methylergometrine group which was highly statistically significant $(p=0.0001)$. There was no prolongation of third stage of labour (more than 30 minutes) in all groups. PPH occurred in $4.11 \%, 3.52 \%$ and $2.94 \%$ of pregnant women in misoprostol, oxytocin and methylergometrine group respectively. Similar results were reported by Gohil et al. ${ }^{6}$ The drop in hemoglobin concentration from before delivery to 48 hours after delivery was $0.625 \mathrm{gm} / \mathrm{dl}$ in misoprostol group, $0.663 \mathrm{gm} / \mathrm{dl}$ in oxytocin group and $0.663 \mathrm{gm} / \mathrm{dl}$ in methylergometrine group. The difference was statistically insignificant.
The two major limitations of the study were firstly the trial was not double blinded and secondly our inability to eliminate the use of additional oxytocics and blood transfusion that results in a probability of masking the drop in hemoglobin concentration.

\section{CONCLUSIONS}

The main interest of the study was in trying to avoid use of intravenous cannulas and needles in countries like ours with a high incidence of HIV infection and where use of disposable needles and IV cannulas are currently unattainable. In our scenario, as most of the women are anemic and they cannot tolerate even mild blood loss, in such situation methylergometrine has the best uterotonic drug profile amongst the drugs used, strongly favouring its routine use as uterotonic for active management of third stage of labor to control PPH and to save women's lives. However, oral misoprostol can be used in prevention of PPH only in those conditions where methergin is not available, and if there is shortage of trained staff for intravenus or intramuscular administration, storage and refrigeration problems.

\section{REFERENCES}

1. Maughan KL, Heim SW, Galazka SS. Preventing post-partum haemorrhage: managing the third stage of labour. AAFP. 2006; 73(6): 1025-8.

2. Fenton JJ, Baumeister LM, Fogarty J. Active management of third stage of labour among American Indian women. Fam Med. 2005;37(6):410-4.

3. Justus HG, Sandra FV, Nikodem C. Misoprostol for treating post partum hemorrhage: a randomized controlled trial [ISRCTN72263357]. BMC Pregnancy Childbirth. 2004; 4:16.

4. Prendiville WJ, Elbourne D, McDonald S. Active versus expectant management in third stage of labour. Cochrane Database System Rev. 2000; (3):CD000007.

5. Patel A, Goudar SS, Geller SE. Drape estimation versus visua assessment for estimating postpartum hemorrhage. Int J Gynecol Obstet. 2006; 95(3):312.

6. Gohil J, Tripathi T, Beenu A. A study to compare the efficacy of misoprostol, oxytocin, methylergometrine and ergometrine oxytocin in reducing blood loss in active management of third stage of labour. J Obstet Gynecol Ind. July-August 2011; 61(4): 408-12. 